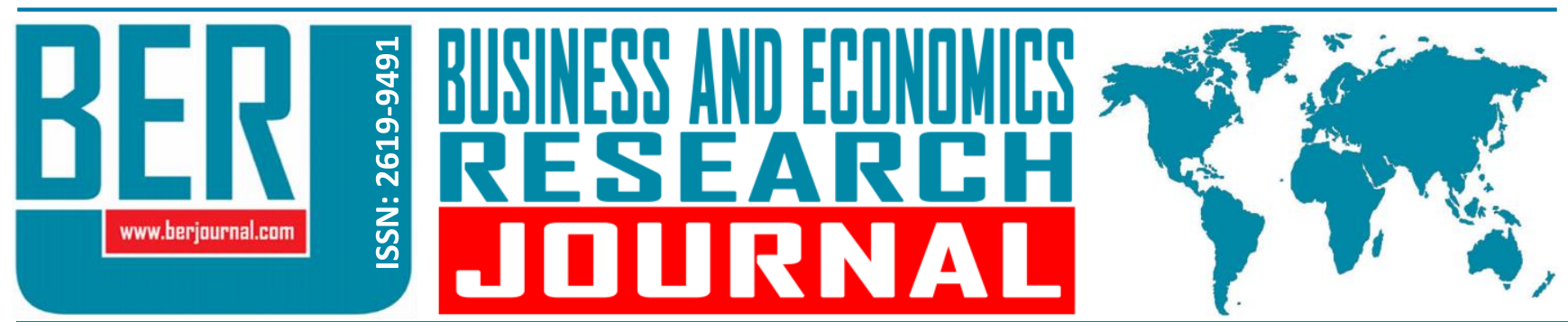

Business and Economics Research Journal Vol. 10, No. 3 Special Issue, 2019, pp. 587-596 doi: 10.20409/berj.2019.187

\title{
Enerji Tüketimi ve Ekonomik Büyüme: NIC Ülkeleri için Ekonometrik Bir Analiz*
}

\section{Fatma Kizilkaya ${ }^{\mathrm{a}}$, Mehmet Dag ${ }^{\mathrm{b}}$}

Öz: Enerji, sosyal ve ekonomik kalkınma için gerekli ve önemli bir girdi olarak kabul edilmektedir. Ekonomik büyüme ve enerji tüketimi birbirleri için neden olabilmektedir. 1971-2014 dönemi yıllık verilerin kullanıldığı bu çalışmada, Yeni Sanayileşmiş Ülkelerde (NIC) enerji tüketimi ve büyüme arasındaki nedensellik ilişkisi incelenmiştir. Çalışmada ilk olarak serilerin yatay kesit bağımlılı̆ı araştırılmıştır. Bulgular yatay kesit bağımlıı̆ı̆ın olduğunu göstermektedir. Sonraki aşamada, seriler arasındaki nedensellik ilişkisi Konya (2006) tarafından geliştirilen bootstrap nedensellik testi kullanılarak incelenmiştir. Sonuçlar, Brezilya, Endonezya, Hindistan, Meksika, Malezya, Tayland, Türkiye ve Güney Afrika için tarafsızlık hipotezinin; Çin ve Filipinler için ise büyüme hipotezinin geçerli olduğunu göstermektedir.

\section{Energy Consumption and Economic Growth: Econometric Analysis for NIC Countries}

Abstract: Energy is considered a necessary and important input for social and economic development. Growth and energy consumption can cause each other. In this study, the causality relationship between energy consumption and growth in Newly Industrialized Countries (NIC) is analysed using annual data from the period 1971-2014. In this study, firstly the cross-sectional dependence of the series is investigated. The findings show that there is cross-sectional dependence in the series. Then the causality relationship between the series is examined using bootstrap causality test developed by Konya (2006). The results show that the neutrality hypothesis is valid for Brazil, Indonesia, India, Mexico, Malaysia, Thailand, Turkey and South Africa, and the growth hypothesis is valid for China and Philippines.

Anahtar Sözcükler: Büyüme Hipotezi, Tarafsızık Hipotezi, Enerji Tüketimi, Büyüme, Bootstrap Nedensellik

JEL: O40, C33, Q40

Geliş : : 28 Ocak 2019

Düzeltme : 13 Şubat 2019

Kabul : : 23 Şubat 2019

Tür $\quad$ : Araştırma

Keywords: Growth Hypothesis, Neutrality Hypothesis, Energy Consumption, Growth, Bootstrap Causality

JEL: O40, C33, Q40

Received : 28 January 2019

Revised : 13 February 2019

Accepted : 23 February 2019

Type :Research

a Lecturer, Hakkari University, Yüksekova Vocational School Department of Business Administration, Hakkari, Turkiye, fatmakizilkaya@hakkari.edu.tr (ORCID ID: 0000-0002-1028-9341)

b Asst. Prof., PhD., Siirt University, Faculty of Economics and Administrative Sciences, Department of Public Finance, Siirt, Turkiye, mehmetdag323@gmail.com (ORCID ID: 0000-0003-2206-2184) 


\section{Giriş}

Üretim sürecinin sürdürülebilmesi açısından enerji, belirleyici role sahip olmasından dolayı günümüzde güncelliğini koruyan konulardan biridir. Özellikle ekonomik büyüme hızlarını artırmayı veya sürdürmeyi hedefleyen ekonomiler için enerji vazgeçilmez bir girdi haline gelmiştir. Enerji, ülkelerin kalkınma politikalarını etkileyen uluslararası boyut taşıyan bir gündem maddesi olarak farklı boyutlarıyla ele alınmaktadır. Büyüme ve enerji tüketimi arasındaki ilişkinin mevcudiyeti enerji politikalarının belirlenmesinde yol gösterici özelliğe sahiptir. Enerji tüketimi ile ekonomik büyüme arasında ilişkinin bulunmadığı durumlarda enerji koruma politikalarının büyümeyi olumsuz etkileme olasılığı ortadan kalkmaktadır. Enerji tüketimi ve ekonomik büyüme arasındaki ilişkiyi tanımlamaya yönelik çalışmalar neticesinde dört temel hipotez ortaya çıkmıştır. Bu hipotezler (Öztürk, 2010:340-341);

1. Tarafsızlık Hipotezi: Bu hipoteze göre enerji tüketimi ve Gayri Safi Yurtiçi Hasıla (GSYH) arasında nedensellik bulunmamaktadır. Bu durum literatürde tarafsızlık hipotezi olarak adlandırılmaktadır. Enerji tüketiminin GSYH ile ilişkili olmadığı, bu nedenle enerji tüketimi ile ilişkili politika değişikliklerinin ekonomik büyüme üzerinde etkisi olmayacağı görüşü bu hipotezin temel görüşünü ortaya koymaktadır.

2. Koruma Hipotezi: Bu hipoteze göre enerji tüketimi ile büyüme arasındaki nedensellik büyümeden enerji tüketimine tek yönlü olarak gerçekleşmektedir. Hipotezin bu şekilde adlandırılmasının nedeni enerji tüketimini azaltmak için tasarlanan enerji koruma politikalarının reel ekonomik büyüme üzerinde olumsuz etkide bulunmayacağını öngörmesidir. Bir başka ifade ile reel ekonomik büyümenin artışının enerji tüketiminde artışa neden olduğu durumlarda koruma hipotezi geçerli olacaktır.

3. Büyüme Hipotezi: Bu hipoteze göre, enerji tüketiminde meydana gelen artış reel GSYH üzerinde artışa neden olmaktadır. Yine hipoteze göre enerji tüketiminin azalmasına yol açan politikalar reel GSYH üzerinde de azaltıcı etkilere yol açacaktır. Buna göre, üretim sürecinde enerji tüketiminin doğrudan ve dolaylı olarak emek ve sermaye faktörlerinin tamamlayıcısı bir fonksiyona sahip olduğu öngörülmektedir.

4. Geri Besleme Hipotezi: Enerji tüketimi ve reel GSYH arasındaki nedenselliğin iki yönlü olduğu ve bu nedenle enerji tüketimi ile reel GSYH'nın birbirini tamamlayıcı bir role sahip olduğu görüşü bu hipotezin temel dayanak noktası olarak ifade edilmektedir. Enerjinin tüketiminde verimliliğin sağlanmasını amaçlayan politikaların reel GSYH üzerinde olumsuz etkilerde bulunmayacağı görüşü bu hipotezin savunduğu bir diğer görüş olarak ifade edilebilir.

Bu çalışmanın temel konusu enerji tüketimi ile büyüme ilişkisinin incelenmesidir. Çalışmanın amacı da daha önce de araştırmalara konu olan enerji tüketimi-büyüme ilişkisini NIC ülkeleri açısından yeni ampirik kanıtlar üzerinden ele almaktır. Çalışmamız dört bölümden oluşmaktadır. Giriş bölümünden sonra konuyla ilgili literatür incelemesi ikinci bölümde ele alınmıştır. Araştırmanın ekonometrik yöntemi ve bulguları üçüncü bölümde sunulmuştur. Dördüncü bölümde ise sonuç ve değerlendirmelere yer verilmiştir.

\section{Literatür İncelemesi}

Literatüre bakıldığında enerji tüketimi ve ekonomik büyüme ilişkisin inceleyen çalışmaların ağırlıkı olarak büyümenin daha fazla enerji tüketimine yol açtığı bulgusuna ulaştığı izlenmektedir. Ekonominin sürdürülebilir bir büyümeye ulaşması enerji politikalarının önemini gün geçtikçe artırmaktadır. Ekonomik büyüme ve enerji ilişkisi ülkelerin sosyal ve ekonomik politikaları üzerinde belirleyici rol oynayabilmektedir. Enerji tüketimi büyümeyi ve dolayısıyla kalkınmayı etkilemesi nedeniyle önemli bir araştırma konusu olmaktadır. Enerji talebinin teknolojik gelişmeler ve talep nedeniyle artmasına karşın dünyadaki enerji kaynaklarının kısıtlı olması enerji politikalarının hassasiyetle belirlenmesini gerektirmektedir.

Enerji tüketimi-büyüme ilişkisine dair literatürde çok sayıda ampirik çalışma bulunmaktadır. Enerji tüketimi ve büyüme arasında nedensel ilişkinin olup olmadığını inceleyen çok sayıda çalışma yapılmış olup Kraft ve Kraft (1978) tarafından yapılan çalışma, bu ilişkiyi araştıran ilk çalışmadır. ABD ekonomisi 1947-1974 dönemi verileri kullanılarak enerji tüketimi ve büyüme arasındaki ilişki incelenmiş ve ekonomik büyümeden enerji tüketimine doğru nedensellik ilişkisinin olduğu belirlenmiştir. Amerika Birleşik Devletleri için yaptıkları çalışmada Akarca ve Long (1980), 1947 ve 1972 yıllarını kapsayan verileri kullanmış ve enerji tüketimi ile 
büyüme arasında bir nedensellik ilişkisinin olmadığını tespit etmişlerdir. Sanayileşmiş ülkeler açısından enerji tüketimi ve büyüme ilişkisini inceleyen bir çalışma Erol ve Yu (1987) tarafından yapılmıştır. Bu çalışmanın bulgularında GSYH'dan enerji tüketimine doğru tek yönlü bir nedenesellik bulunmuştur. ABD için çok değişkenli eşbütünleşme modelleri kullanarak enerji tüketimi ile GSYH arasındaki ilişkiyi incelemek amacıyla yaptığı çalışmalarda Stern, (1993) ve (2000), her iki çalışmada da bir ilişki bulamamıştır. Granger nedensellik analizi kullanarak yaptığı çalışmada Tayvan için enerji tüketimi ile GSYH arasındaki nedenselliği araştıran Cheng (1997), 1953-1993 dönemi için GSYH'dan enerji tüketimine nedensellik bulunduğu bulgusuna ulaşmıştır. Tayvan ve Güney Kore için Masih ve Masih (1997), enerji tüketimi, reel gelir ve enerji fiyatları değişkenlerini kullanarak, bir çalışma yapmışlar ve çalışma sonucunda enerji tüketimi ile GSYH arasında iki yönlü bir ilişki bulmuşlardır. Asafu ve Adjaye (2000), seçilmiş bazı Asya ülkeleri için yaptıkları çalışmada Tayland ve Filipinler için enerji tüketimi ve büyüme açısından iki yönlü nedensellik, Hindistan ve Endonezya için enerji tüketiminden büyümeye olan tek yönlü nedensellik ilişkisini tespit etmişlerdir.

Yunanistan için enerji tüketimi ve büyüme arasındaki ampirik ilişkiyi Hondroyiannis, Lolos ve Papapetrou (2002) araştırmışlardır. Enerji tüketimi, reel GSYH ve fiyat gelişmeleri dahil olmak üzere vektör hata düzeltme modeli tahmininin kullanıldığı bu çalışmada 1960-2016 dönemi için elde edilen bulgular üç değişken arasındaki uzun dönemli bir ilişki olduğunu göstermiştir. Çin için elektrik tüketimi ve reel GSYH arasındaki ilişkinin araştırıldığı çalışmada, Shiu ve Lum (2003), iki değişken arasında eşbütünleşme ilişkisinin olduğu sonucuna varmışlardır. Elektrik tüketiminden reel GSYH'ya tek yönlü nedensellik olduğu bulgusu çalışmanın bir diğer bulgusudur. Türkiye için enerji tüketimi ile GSYH arasında nedenselliğin olup olmadığı Soytaş ve Sarı (2003) tarafından araştııılmıs ve 1960-1965 ve 1950-1992 yılları arasında enerji tüketiminden GSYH'ya nedenselliğin olduğu bulgusu elde edilmiştir. Türkiye'de 1950-2000 dönemi için yaptıkları çalışmada, Altınay ve Karagöl (2004), enerji tüketimi ve GSYH arasındaki nedenselliği araştırmış ve söz konusu dönemde nedensellik ilişkisi olmadığı sonucuna varmışlardır. Wolde-Rufael (2006) tarafından yapılan çalışmada kişi başına elektrik tüketimi ile kişi başı GSYH verileri kullanılarak 1971-2001 dönemi ve 17 Afrika ülkesi için eşbütünleşme ve nedensellik ilişkisi test edilmiştir. Çalışmanın sonuçları, 9 ülke için değerişkenler arasında uzun dönemli ilişkinin olduğunu göstermektedir. Ayrıca 6 ülke için, kişi başı reel GSYH'dan kişi başı elektrik tüketimine; 3 ülke için kişi başı elektrik tüketiminden kişi başı reel GSYH'dan doğru nedensellik ilişkisi elde edilmiştir. 3 ülke için ise iki yönlü nedensellik ilişkisi elde edilmiştir.

Seçilmiş 11 petrol ihracatçısı ülkedeki kişi başı enerji tüketimi ve kişi başı GSYH arasındaki nedensel ilişkiyi panel birim kök ve panel eşbütünleşme testleri kullanarak inceleyen Mehrara (2007), petrol ihraç eden ülkeler için ekonomik büyümeden enerji tüketimine doğru güçlü bir nedensellik olduğu sonucuna varmıştır. Reel GSYH ve enerji tüketimi arasındaki nedensellik ilişkisini, Erdal, Erdal ve Esengün (2008), Johansen eşbütünleşme ve Granger nedensellik testini kullanarak araştırmışlardır. 1970-2006 dönemi için iki yönlü bir nedensellik olduğu analizin sonucu olarak elde edilmiştir. G-7 ülkelerindeki sermaye oluşumu, enerji tüketimi ve reel GSYH arasındaki ilişkiyi Narayan ve Smyth (2008), panel birim kök ve Granger nedensellik kullanarak araştırmışlardır. Çalışma bulguları, sermaye oluşumunun, enerji tüketiminin ve reel GSYH'nın birbiriyle ilişkili olduğunu ve sermaye oluşumunun ve enerji tüketiminin uzun dönemde reel GSYH'ya olumlu etkide bulunduğunu ortaya koymaktadır.

Belloumi (2009), 1971-2004 döneminde kişi başı enerji tüketimi ve kişi başı GSYH değişkenleri arasındaki nedensellik ilişkisini incelemiştir. Çalışmanın sonuçlarına göre Tunus için kişi başı GSYH ile kişi başı enerji tüketimi arasında eşbütünleşme ilişkisi bulunmaktadır. Ayrıca enerji tüketiminden GSYH'ya kısa dönemli ve tek yönlü nedensellik ilişkisinin olduğu sonucuna varılmıştır. Pao (2009), 1980-2007 yılları arasında Tayvan'daki elektrik tüketimi ile büyüme arasındaki nendensellik ilişkileri hata düzeltme modeli kullanılarak incelemiştir. Sonuçlar, elektrik tüketimi ve reel GSYH'nın ilişkili olduğunu ve ekonomik büyümeden elektrik tüketimine tek yönlü kısa ve uzun dönem nedenselliğinin olduğunu, tersi yönde bir nedenselliğin olmadığını göstermektedir.

11 Afrika ülkesi için (Fildişi Sahili, Gambiya, Gana, Kamerun, Senegal, Sudan ve Zimbabwe, Kenya, Nijerya, Togo) ARDL eşbütünleşme ve Granger nedensellik testini kullanarak yaptı̆̆ı çalışmada Akinlo (2008), enerji tüketimi ile büyüme arasındaki ilişkiyi incelemiştir. Çalışma sonucuna göre, Kamerun, Fildişi Sahili, Gambiya, Gana, Senegal, Sudan ve Zimbabwe için değişkenler arasında eşbütünleşme ilişkisinin olduğu bulgusuna ulaşılmıştır. Gambiya, Gana ve Senegal için enerji tüketimi ile ekonomik büyüme arasında iki yönlü 
bir nedensellik ilişkisinin olduğu çalışmanın bir diğer bulgusudur. Bununla birlikte, çalışmanın analiz sonuçları Sudan ve Zimbabwe için büyümeden enerji tüketimine doğru nedensellik olduğunu göstermektedir. Kamerun ve Fildişi Sahili açısından ise tarafsızlık hipotezi geçerlidir.

1985-2005 dönemi için 20 OECD ülkesinde panel veri yöntemleri ile yaptıkları çalışmada Apergis ve Payne (2010), çok değişkenli bir çerçevede, yenilenebilir enerji tüketimi ve büyüme arasındaki ilişkiyi incelemişlerdir. Çalışmada değişken olarak reel GSYH, yenilenebilir enerji tüketimi, sabit sermaye oluşumu ve işgücü miktarı kullanılmıştır. Granger nedensellik testi sonuçlarına göre gerek kısa gerekse uzun dönemde yenilenebilir enerji tüketimi ile ekonomik büyüme arasında iki yönlü nedensellik olduğu bulgusu elde edilmiştir. 1981'den 2007'ye kadar olan dönemde 25 OECD ülkesi için Belke, Dobnik ve Dreger (2011), enerji fiyatları da dahil olmak üzere, enerji tüketimi ile reel GSYH arasındaki uzun dönemli ilişkiyi araştırmıştır. Enerji tüketimi ile reel GSYH arasındaki uzun dönemli ilişki olduğu ve bu ilişki üzerinde uluslararası gelişmelerin etkili olduğu çalışmanın temel bulguları arasındadır. Elde edilen bulgular enerji tüketiminin fiyat esnekliği olmadığını göstermekte olup çalışmada uygulanan nedensellik testleri, enerji tüketimi ve büyüme arasındaki iki yönlü nedensel ilişkinin varlığını göstermiştir.

20 OECD ülkeside enerji tüketimi ve büyüme arasındaki nedensel ilişkiyi Bozoklu ve Yılancı (2013) panel veri analizi kullanarak incelemiştir. GSYH'dan enerji tüketimine doğru olan nedensellik açısından, Avustralya, Avusturya ve Kanada için geçici bir ilişki olduğu çalışmanın bulguları arasındadır. GSYH'dan enerji tüketimine kalıı bir ilişki bulgusu İtalya, Japonya, Meksika, Hollanda, Portekiz, İngiltere, ABD ve Avusturya, Belçika, Danimarka, Almanya, İtalya, Japonya, Hollanda, Norveç ve ABD için elde edilmiştir. Bunun yanında, enerji tüketiminden GSYH'ya doğru Avusturya, Danimarka, İtalya, Hollanda, Norveç ve Portekiz için geçici bir nedensellik ilişkisi ve Belçika, Finlandiya, Yunanistan, İtalya, Japonya ve Portekiz için kalıcı bir nedensellik ilişkisi bulunduğu bulgusuna ulaşımıştır.

Güney Asya ülkelerinin büyümesini etkileyen faktörleri belirlemek için Khan, Khan, Zaman, Irfan ve Khatab (2014), 1975-2011 dönemine ait enerji tüketimi, büyüme ve finansal gelişme verilerini eşbütünleşme ve nedensellik testleri ile analiz etmişlerdir. Güney Asya ülkelerinde enerji tüketimi, büyüme ve finansal gelişme arasında iki yönlü nedensellik bulunduğu çalışmanın ortaya koyduğu sonuç olarak ifade edilmiştir.

1990-2012 dönemine ilişkin enerji tüketimi ve $\mathrm{CO}_{2}$ emisyonlarının ekonomik büyüme üzerindeki etkisini 58 ülkeye ait verileri kullanarak incelemek amacıyla yaptıkları çalışmada Saidi ve Hammami (2015), dinamik panel veri analizi yöntemini kullanmıştır. 58 ülke, Avrupa ve Kuzey Asya, Latin Amerika ve Karayipler ve Sahra Altı, Kuzey Afrika ve Orta Doğu şeklinde bölge grupları şeklinde gruplanmıştır. Ele alınan tüm bölgeler için $\mathrm{CO}_{2}$ emisyonlarının enerji tüketimi üzerinde anlamlı ve pozitif bir etkiye sahip olduğu gözlenmiştir. Bunun yanında çalışmanın bulguları ekonomik büyümenin enerji tüketimi üzerinde pozitif bir etkisi olduğunu göstermiştir.

1990-2009 döneminde yeni $A B$ üye ülkeleri için ekonomik büyüme, yenilenebilir enerji tüketimi, sermaye ve işgücü arasındaki nedenselliği inceleyen Alper ve Oğuz (2016), çalışmalarında asimetrik nedensellik testi yaklaşımı ve otoregresif dağıtılmış gecikme (ARDL) yaklaşımı kullanmıştır. Yenilenebilir enerji tüketiminin, incelenen tüm ülkeler için ekonomik büyüme üzerinde pozitif etkileri olduğunu çalışmanın temel bulgusudur. Buna karşın ülkelerden yalnızca Bulgaristan, Estonya, Polonya ve Slovenya için enerji tüketiminin ekonomik büyüme üzerinde anlamlı bir etkisi olduğu sonucuna ulaşılmışır. Ayrıca Kıbrıs, Estonya, Macaristan, Polonya ve Slovenya için tarafsızlık hipotezi desteklenmektedir.

Ekonomik Kalkınma ve İşbirliği Teşkilatı (OECD) üyesi 29 ülkeyi incelendiği çalışmada Gözgör, Lau ve Lu (2017), 1990-2013 yıllarını kapsayan dönemde panel veri analizi kullanarak yenilenebilir ve yenilenemeyen enerji tüketiminin ekonomik büyüme üzerindeki etkilerini ampirik olarak analiz etmiştir. Panel ARDL ve panel kantil regresyon (PQR) tahminleri kullanılarak elde edilen sonuçlar yenilenemeyen ve yenilenebilir enerji tüketiminin daha yüksek bir ekonomik büyüme oranı ile pozitif ilişkili olduğunu göstermektedir.

1990-2012 dönemi için 72 ülkede ekonomik büyüme, yenilenebilir enerji ve ticaret ilişkisini inceleyen Amri (2017), dinamik panel veri analizi yaklaşımını kullanmıştır. Çalışmanın analiz kısmında ele alınan ülkeler üç gruba ayrılarak incelenmiştir. Bulgulara göre, gelişmekte olan ve gelişmiş ülkelerde büyüme ile yenilenebilir enerji tüketimi arasında geri beslemeli bir ilişki bulunmaktadır. 


\section{Ekonometrik Yöntem ve Bulgular}

1971-2014 dönemi yıllık verilerin kullanıldığı bu çalışmada, Yeni Sanayileşmiş Ülkelerde (NIC: Brezilya, Çin, Endonezya, Hindistan, Meksika, Malezya, Filipinler, Tayland, Türkiye ve Güney Afrika) büyüme ve enerji tüketimi ilişkisi incelenmiştir. Çalışmada enerji kullanımı (kişi başına düşen petrol eşdeğeri kg) ve kişi başı reel GSYH verileri kullanılmıştır. Ele alınan serilerde nedensellik ilişkisinin varlığı Konya (2006) tarafından geliştirilen panel bootstrap nedensellik testi kullanılarak incelenmiştir. Analizde kullanılan veriler Dünya Bankası (http://data.worldbank.org) web sayfasından elde edilmiştir. Değişkenlerin logaritmik dönüşümleri yapıldıktan sonra analizlerde kullanılmıştır.

\subsection{Yatay Kesit Bağımlılığı ve Heterojenlik Testleri}

Panel veride değişkenler arasında nedensellik ilişkisini test etmek için öncelikle panel üyeleri arasında olası bir yatay kesit bağımlılı̆ını ve eğim heterojenliğini araştırmak gerekmektedir. Eğer yatay kesit bağımlılı̆ı varsa, panel veri nedenselliği tahmin edilirken, Görünürde İlişkisiz Regresyon (SUR) yaklaşımının kullanılması en küçük karelerden (EKK) daha verimli olacaktır. Buna ek olarak, Pesaran (2006) yatay kesit bağımlılığı olduğu durumda göz ardı edilmesinin önemli yanlılık ve boyut bozulmalarının meydana geleceğini belirtmiştir. Diğer taraftan, panel verilerinin homojenlik özelliğine sahip olduğunu varsayarsak, ülkeye özgü karakteristikleri gösteren ülkeler arasındaki heterojenlik yakalanmayacaktır (Hsueh, Hu ve Tu, 2013: 296). Bu nedenle çalışmada öncelikle ülkeler arasındaki yatay kesit bağımlılığı ve eğim heterojenliğinin olup olmadığı incelenecektir.

Yatay kesit bağımlılı̆ını dikkate almanın ardındaki mantık, bir ülkeyi etkileyen bir şokun, uluslararası ticaret ve finansal entegrasyonun yanı sıra, yüksek derecede küreselleşme nedeniyle diğer ülkeleri de etkileyebileceğidir (Kar, Nazlıoğlu ve Ağır, 2011: 688). Seriler arasında yatay kesit bağımlılığının varlığı, Berusch-Pagan (1980) $L M$ testi $\left(C_{B P}\right)$ ile ya da Pesaran (2004) $C D$ testi ile incelenebilmektedir. $C D_{B P}$ testi zaman boyutunun büyük yatay kesit boyutunun küçük olduğu durumlarda, Pesaran $C D$ testi ise yatay kesit boyutunun büyük zaman boyutundan küçük olduğu durumlarda kullanılabilmektedir. Ancak Pesaran CD testi, kitle ortalaması ikili korelasyonları sıfır olduğunda düşük güce sahiptir. Ayrıca faktör yüklerinin yatay kesit boyutunda sıfır ortalamaya sahip olması durumunda, Pesaran CD testi durağan dinamik panel veri modellerinde sıfır hipotezini reddedemeyecekti. Pesaran Ullah ve Yamagata (2008), bu problemleri çözebilmek amacıyla $C_{B P}$ testinin kesin ortalamasını ve varyansını kullanarak $C_{B P}$ testinin sapması düzeltilmiş versiyonunu $\left(L M_{a d j}\right)$ önermişlerdir. Sapması düzeltilmiş LM test istatistiği Denklem (1) ile verilmiştir.

$$
L M_{a d j}=\left(\frac{2}{N(N-1)}\right)^{1 / 2}\left(\sum_{i=1}^{N-1} \sum_{j=i+1}^{N} \hat{\rho}_{i j} \frac{(T-k) \hat{\rho}_{i j}^{2}-\mu_{T i j}}{v_{T i j}}\right)
$$

Burada, $k$ regresör sayısını $\mu_{T i j}$ ve $v_{T i j}$ ise $(T-k) \hat{\rho}_{i j}^{2}$ 'nin kesin ortalaması ve varyansını göstermektedir.

Diğer bir önemli konu ise her bir panel için tahmin edilen parametrelerde heterojenliği dikkate almaktır. Swamy (1970), ülkeler arası heterojenliği belirlemek için aşağıda verilen eğim homojenliği testini önermiştir.

$$
\tilde{S}=\sum_{i=1}^{N}\left(\hat{\beta}_{i}-\tilde{\beta}_{W F E}\right)^{\prime} \frac{x_{i}^{\prime} M_{T} x_{i}}{\tilde{\sigma}_{i}^{2}}\left(\hat{\beta}_{i}-\tilde{\beta}_{W F E}\right)
$$

Burada $\hat{\beta}_{i}$ havuzlanmış EKK tahmincisi, $\tilde{\beta}_{W F E}$ ağırlıklandırıımış sabit etkiler havuzlanmış tahmincisi, $M_{T}$ birim matris ve $\tilde{\sigma}_{i}^{2}$ ise $\sigma_{i}^{2 \prime}$ nin tahmincisidir. Pesaran ve Yamagata (2008) aşağıdaki standartlaştırılmış dağııım istatistiklerini geliştirmişlerdir: 
$\widehat{\Delta}=\sqrt{N}\left(\frac{N^{-1} \tilde{S}-k}{\sqrt{2 k}}\right)$

$\widehat{\Delta}$ testinin küçük örnek özellikleri, normal olarak dağıtılmış hatalar altında aşağıda sapması düzeltilen versiyon kullanarak geliştirilebilir:

$$
\widehat{\Delta}_{a d j}=\sqrt{N}\left(\frac{N^{-1} \tilde{S}-E\left(\tilde{z}_{i t}\right)}{\sqrt{\operatorname{var}\left(\tilde{z}_{i t}\right)}}\right)
$$

Burada $E\left(\tilde{z}_{i t}\right)=k, \operatorname{var}\left(\tilde{z}_{i t}\right)=2 k(T-k-1) /(T+1)^{\prime}$ dir.

Yatay kesit bağımlılı̆ı ve homojenlik testi sonuçları Tablo 1 ile verilmiştir.

Tablo 1. Yatay Kesit Bağımlılı̆̆ ve Heterojenlik Testi Sonuçları

\begin{tabular}{|c|c|c|}
\hline Yöntem & Test İstatistiği & p-değeri \\
\hline \multicolumn{3}{|c|}{ Yatay Kesit Bağımlılığı Testi } \\
\hline CD ${ }_{B P}$ (Breusch -Pagan 1980) & $228,114 *$ & 0,000 \\
\hline Pesaran CD (Pesaran 2004) & $-1,540 * * *$ & 0,062 \\
\hline LMadj (Pesaran vd. 2008) & $64,340^{*}$ & 0,000 \\
\hline \multicolumn{3}{|c|}{ Homojenlik Testi } \\
\hline$\widehat{\Delta}$ & $2,805^{*}$ & 0,003 \\
\hline$\widehat{\Delta}_{\mathbf{a d j}}$ & $2,904 *$ & 0,002 \\
\hline
\end{tabular}

Not: $*, * *$ ve $* * *$ sırasıyla $\% 1, \% 5$ ve $\% 10$ düzeyinde anlamlılığı göstermektedir.

Tablo 1 incelendiğinde, $\mathrm{CD}_{\mathrm{BP}}$, Pesaran $\mathrm{CD}$ ve $\mathrm{LM}_{\mathrm{adj}}$ testleri için yatay kesit bağımlılığının olmadı̆̆ı şeklinde ifade edilen sıfır hipotez reddedilmiş ve yatay kesit bağımlılığının olduğuna karar verilmiştir. B sonuca göre bir NIC ülkesindeki herhangi bir şok diğer ülkeleri de etkilemektedir. Ayrıca SUR sistem tahmincisinin kullanımı ülke bazında havuzlanmış EKK tahmincisinden daha uygun olacaktır. Yine Tablo $1^{\prime}$ den $\widehat{\Delta}$ ve $\widehat{\Delta}_{\text {adj }}$ testleri için homojenliği gösteren sıfır hipotezi reddedilmiş ve eğim katsayılarının heterojen olduğu sonucuna ulaşılmıştır.

\subsection{Bootstrap Panel Nedensellik Testi}

Konya (2006) bootstrap nedensellik testi Görünürde İlişkisiz Regresyon (SUR) modellerine ve ülkeye özgü bootstrap kritik değerlere sahip Wald testine dayanmaktadır. Bu yaklaşım iki önemli avantaja sahiptir. Bunlar panel bootstrap nedensellik testinin tüm panel üyeleri için ortak hipotez gerektirmemesi ve gecikme yapısının belirlenmesinden başka ön test (birim kök ve eşbütünleşme) gerektirmemesidir (Konya, 2006: 990). Panel bootstrap nedensellik testi için kullanılacak denklem kümesi Denklem (5) ve Denklem (6)'da verilmiştir.

$$
\begin{gathered}
Y_{1, t}=\alpha_{1,1}+\sum_{l=1}^{m l y_{1}} \beta_{1,1, l} Y_{1, t-l}+\sum_{l=1}^{m l x_{1}} \delta_{1,1, l} X_{1, t-l}+\varepsilon_{1,1, t} \\
Y_{2, t}=\alpha_{1,2}+\sum_{l=1}^{m l y_{1}} \beta_{1,2, l} Y_{2, t-l}+\sum_{l=1}^{m l x_{1}} \delta_{1,2, l} X_{2, t-l}+\varepsilon_{1,2, t} \\
\vdots \\
Y_{N, t}=\alpha_{1, N}+\sum_{l=1}^{m l y_{1}} \beta_{1, N, l} Y_{N, t-l}+\sum_{l=1}^{m l x_{1}} \delta_{1, N, l} X_{N, t-l}+\varepsilon_{1, N, t}
\end{gathered}
$$




$$
\begin{gathered}
X_{1, t}=\alpha_{2,1}+\sum_{l=1}^{m l y_{2}} \beta_{2,1, l} Y_{1, t-l}+\sum_{l=1}^{m l x_{2}} \delta_{2,1, l} X_{1, t-l}+\varepsilon_{2,1, t} \\
X_{2, t}=\alpha_{2,2}+\sum_{l=1}^{m l y_{2}} \beta_{2,2, l} Y_{2, t-l}+\sum_{l=1}^{m l x_{2}} \delta_{2,2, l} X_{2, t-l}+\varepsilon_{2,2, t} \\
\vdots \\
X_{N, t}=\alpha_{2, N}+\sum_{l=1}^{m l y_{2}} \beta_{2, N, l} Y_{N, t-l}+\sum_{l=1}^{m l x_{2}} \delta_{2, N, l} X_{N, t-l}+\varepsilon_{2, N, t}
\end{gathered}
$$

Burada $\mathrm{N}$ panelin ülke sayısını $(i=1, \ldots, N), t$ zaman boyutunu $(t=1, \ldots, T), l$ ise gecikme uzunluğunu ifade etmektedir. Bu denklem sisteminde nedenselliği test etmek için, ülke $\mathrm{j}$ için alternatif nedensellik ilişkilerin bulunması muhtemeldir: Örneğin Denklem (5) ve (6) incelendiğinde eğer bütün $\delta_{1, j, l}$ 'ler sıfır değil fakat bütün $\beta_{2, j, l}$ 'ler sıfır ise X'ten Y'ye tek yönlü Granger nedensellik bulunmaktadır. Eğer bütün $\delta_{1, j, l}$ 'ler sıfır fakat bütün $\beta_{2, j, l}$ 'ler sıfır değil ise Y'den X'e tek yönlü Granger nedensellik vardır. Eğer ne $\delta_{1, j, l}$ 'ler ne de $\beta_{2, j, l}$ 'ler sıfır değil ise X ve Y arasında iki yönlü Granger nedensellik vardır. Eğer bütün $\delta_{1, j, l}$ 'ler ve $\beta_{2, j, l}$ 'ler sıfır ise X ve Y arasında Granger nedensellik yoktur (Kar vd., 2011: 689; Menyah, Nazlioglu ve Wolde-Rufael, 2014: 392). Eğer Wald-istatistiği kritik değerden büyükse değişkenler arasında nedensellik ilişkisi yoktur şeklinde olan sıfır hipotezi reddedilmektedir. Panel bootstrap nedensellik sonuçları Tablo 2 ile sunulmuştur.

Tablo 2. Bootstrap Panel Nedensellik Testi Sonuçları

\begin{tabular}{|c|c|c|c|c|}
\hline \multirow{2}{*}{ Ülkeler } & \multicolumn{2}{|c|}{$\begin{array}{c}\text { Ho: Enerji tüketimi, büyümenin nedeni } \\
\text { değildir. }\end{array}$} & \multicolumn{2}{c|}{$\begin{array}{c}\text { Ho: Büyüme, enerji tüketiminin nedeni } \\
\text { değildir. }\end{array}$} \\
\cline { 2 - 5 } & Wald İstatistiği & p-değeri & Wald istatistiği & p-değeri \\
\hline Brezilya & 31,419 & 0,766 & 6,568 & 0,993 \\
\hline Çin & $2,507^{* * *}$ & 0,090 & 0,539 & 0,991 \\
\hline Endonezya & 0,395 & 0,992 & 4,258 & 0,931 \\
\hline Hindistan & 8,383 & 0,950 & 8,278 & 0,934 \\
\hline Meksika & 0,291 & 0,990 & 0,227 & 0,990 \\
\hline Malezya & 0,433 & 0,990 & 10,166 & 0,990 \\
\hline Filipinler & $5,759 * *$ & 0,012 & 0,001 & 0,963 \\
\hline Tayland & 9,718 & 0,187 & 10,550 & 0,999 \\
\hline Türkiye & 0,026 & 0,990 & 3,198 & 0,990 \\
\hline Güney Afrika & 0,397 & 0,994 & 0,479 & 0,773 \\
\hline
\end{tabular}

Not: $*, * *$ ve $* * *$ sırasıyla, $\% 1, \% 5$ ve $\% 10$ düzeyinde anlamlılı̆̆ı göstermektedir. Bootstrap kritik değerler 10.000 döngüyle elde edilmiştir.

Tablo 2 ile verilen Wald istatistikleri incelenirse enerji tüketiminin, büyümenin nedeni değildir sıfır hipotezi Çin ve Filipinler için reddedilmektedir. Yani Çin ve Filipinler için enerji tüketiminden büyümeye nedensellik elde edilmiştir. Büyüme, enerji tüketiminin nedeni değildir sıfır hipotezi ise bütün NIC ülkeleri için reddedilememektedir. Yani NIC ülkeleri için büyümeden enerji tüketimine nedensellik ilişkisi elde edilememiştir. 


\section{Sonuç}

Enerji, her türlü üretim faaliyeti için hayati önem taşmakta olup ve ekonomik büyüme için öncü bir güç olarak değerlendirmektedir. Hem enerji hem de ekonomik büyüme birbiriyle ilişkili olabilmekte ve birbirini etkileyebilmektedir. Buna göre, ekonomik büyüme, enerji talebinde bir artışa yol açmakta ve enerji, ekonomik büyümeyi elde etmek için ana girdilerden biridir. Büyüme ve enerji arasındaki ilişkinin türü ve boyutuna ilişkin çalışmalar yürütülmektedir.

Bu çalışmada, NIC ülkelerinde enerji tüketimi ile büyüme arasında nedensellik ilişkisi araştırılmıştır. Bootstrap nedensellik sonuçları Çin ve Filipinler için enerji tüketiminden büyümeye doğru nedenselliğin olduğunu göstermektedir. Ayrıca NIC ülkelerinin hiçbirinde büyümeden enerji tüketimine nedensellik ilişkisi bulunamamıştır. Elde edilen bulgular Brezilya, Endonezya, Hindistan, Meksika, Malezya, Tayland, Türkiye ve Güney Afrika için tarafsızlık hipotezinin; Çin ve Filipinler için ise büyüme hipotezinin geçerli olduğunu göstermektedir.

Bu çalışmada, literatürdeki çalışmalardan Stern $(1993,2000)$ ve Altınay ve Karagöl (2004) ile benzer bulgulara ulaşılmıştır. Tarafsızlık hipotezinin desteklendiği ülkeler için, enerji tüketimi ile ilgili politika düzenlemelerinin ekonomik politikayı etkileyemeyeceği görülmektedir. Bu nedenle bu ülkelerin gelir politikaları geliştirirken enerji tüketimi ile büyüme arasında ilişki bulunmadığını dikkate alması mümkündür. Bu ülkelerde enerji tüketimi üzerinden alınan vergilere artışa gidilmesi büyümeyi olumsuz etkilemeyecek ve böylelikle bu alandaki vergiler artırılarak kamu gelirlerinde artış sağlanabilecektir.

Öte yandan, çalışmanın bulgularına göre büyüme hipotezinin geçerli olduğu ülkeler açısından ise (Çin ve Filipinler) enerji teşvik politikalarının ekonomik büyüme üzerinde koruma politikalarına oranla daha fazla destekleyici rol oynayacağı öngörülmektedir. Gelecekteki çalışmalarda enerji tüketimi-büyüme ilişkisinin incelenmesi durumunda çalışmalarda büyümeyi etkileyen diğer faktörlerin de analizlere daha edilmesi bu alanda daha detaylı analizler yapılması hususunda fayda sağlayabilecektir.

\section{Son Notlar}

* Bu çalışma, 28-29-30 Kasım 2018 tarihlerinde düzenlenen "IV. International Conference on Applied Economics and Finance \& Extended with Social Sciences (ICOAEF'18)" kongresinde sözlü olarak sunulmuş ve öz kısmı Bildiri Özetleri Kitabında yayınlanmıştır.

\section{Kaynaklar}

Akarca, A. T., \& Long, T. V. (1980). On the relationship between energy and GNP: A reexamination. The Journal of Energy and Development, 326-331.

Akinlo, A. E. (2008). Energy consumption and economic growth: Evidence from 11 Sub-Sahara African countries. Energy Economics, 30(5), 2391-2400.

Alper, A., \& Oguz, O. (2016). The role of renewable energy consumption in economic growth: Evidence from asymmetric causality. Renewable and Sustainable Energy Reviews, 60, 953-959.

Altınay, G., \& E. Karagöl (2004). Structural break, unit root, and the causality between energy consumption and GDP in Turkey. Energy Economics, 26, 985-994.

Amri, F. (2017). Intercourse across economic growth, trade and renewable energy consumption in developing and developed countries. Renewable and Sustainable Energy Reviews, 69, 527-534.

Apergis, N., \& Payne, J. E. (2010). Renewable energy consumption and economic growth: Evidence from a panel of OECD countries. Energy Policy, 38(1), 656-660.

Asafu-Adjaye, J. (2000). The relationship between energy consumption, energy prices and economic growth: Time series evidence from Asian developing countries. Energy Economics, 22, 615-625.

Belke, A., Dobnik, F., \& Dreger, C. (2011). Energy consumption and economic growth: New insights into the cointegration relationship. Energy Economics, 33(5), 782-789. 
Belloumi, M. (2009). Energy consumption and GDP in Tunisia: Cointegration and causality analysis. Energy Policy, 37, 2745-2753.

Bozoklu, S., \& Yilanci, V. (2013). Energy consumption and economic growth for selected OECD countries: Further evidence from the Granger causality test in the frequency domain. Energy Policy, 63, 877-881.

Breusch, T. S., \& Pagan, A. R. (1980). The Lagrange multiplier test and its applications to model specification in econometrics. The Review of Economic Studies, 47(1), 239-253.

Cheng S. B., Lai, W.T. (1997). An Investigation of co-integration and causality between energy consumption and economic activity in Taiwan, Province of Chine. Energy Economics, 19, 435-444.

Chu, H. P. (2012). Oil consumption and output: What causes what? Bootstrap panel causality for 49 countries. Energy Policy, 51, 907-915.

Erdal, G., Erdal, H., \& Esengün, K. (2008). The causality between energy consumption and economic growth in Turkey. Energy Policy, 36, 3838-3842.

Erol, U., \& Yu, E. S. H. (1987). On the causal relationship between energy and income for industrializing countries. Journal of Economics and Developments, 13, 113-122.

Gozgor, G., Lau, C. K. M., \& Lu, Z. (2018). Energy consumption and economic growth: New evidence from the OECD countries. Energy, 153, 27-34.

Hondroyiannis, G., Lolos, S., \& Papapetrou, E. (2002). Energy consumption and economic growth: assessing the evidence from Greece. Energy Economics, 24(4), 319-336.

Hsueh, S. J., Hu, Y. H., \& Tu, C. H. (2013). Economic growth and financial development in Asian countries: A bootstrap panel Granger causality analysis. Economic Modelling, 32, 294-301.

Kar, M., Nazlıoğlu, Ş., \& Ağır, H. (2011). Financial development and economic growth nexus in the MENA countries: Bootstrap panel granger causality analysis. Economic Modelling, 28(1-2), 685-693.

Khan, M. A., Khan, M. Z., Zaman, K., Irfan, D., \& Khatab, H. (2014). Questing the three key growth determinants: Energy consumption, foreign direct investment and financial development in South Asia. Renewable Energy, 68(C), 203215.

Kónya, L. (2006). Exportsandgrowth: Granger causality analysis on OECD countries with a panel data approach. Economic Modelling, 23(6), 978-992.

Kraft, J., \& Kraft, A. (1978). On the relationship between energy and GNP. Journal of Energy Development 3, 401-403.

Masih, A. M. M., Masih R. (1997). On the temporal causal relationship between energy consumption, real income and prices: Some evidence from Asian-energy dependent NICs based on a multivariate cointegration/ vector error correction approach. Journal of Policy Modelling, 19, 417-440.

Mehrara, M. (2007). Energy consumption and economic growth: The case of oil exporting countries. Energy Policy, 35, 2939-2945

Menyah, K., Nazlioglu, S., \& Wolde-Rufael, Y. (2014). Financial development, trade openness and economic growth in African countries: New insights from a panel causality approach. Economic Modelling, 37, 386-394.

Narayan, P. K., \& Smyth, R. (2008). Energy consumption and real GDP in G7 countries: New evidence from panel cointegration with structural breaks. Energy Economics, 30(5), 2331-2341.

Öztürk, İ. (2010). A literature survey on energy-growth nexus. Energy Policy, 38, 340-349.

Pao, H.T. (2009). Forecast of electricity consumption and economic growth in Taiwan by state space modeling. Energy 34, 1779-1791.

Pesaran, M. H. (2004). General diagnostic tests for cross section dependence in panels. Journal of Econometrics 142 , 50-93.

Pesaran, M. H. (2006). Estimation and inference in large heterogeneous panels with a multifactor error structure. Econometrica, 74(4), 967-1012.

Pesaran, M. H., \& Yamagata, T. (2008). Testing slope homogeneity in large panels. Journal of Econometrics, 142(1), 5093.

Pesaran, M. H., Ullah, A., \& Yamagata, T. (2008). A bias adjusted LM test of error cross-section independence. The Econometrics Journal, 11(1), 105-127.

Saidi, K., \& Hammami, S. (2015). The impact of CO 2 emissions and economic growth on energy consumption in 58 countries. Energy Reports, 1, 62-70.

Shiu, A., \& Lum, P. L. (2003). Electricity consumption and economic growth in China. Energy Policy, 32(1), 47-54. 
Soytas, U., \& Sari, R. (2003). Energy consumption and GDP: Causality relationship in G-7 countries and emerging markets. Energy Economics, 25(1), 33-37.

Stern, D. I. (1993). Energy and economic growth in the USA. Energy Economics, 15, 137-150.

Stern, D. I. (2000). Multivariate cointegration analysis of the role of energy in the US macroeconomy. Energy Economics, 22, 267-283.

Wolde-Rufael, Y. (2006). Electricity consumption and economic growth: A time series experience for 17 African countries. Energy Policy, 34(10), 1106-1114. 